\title{
COME TOGETHER NOW! \\ NEW TECHNOLOGIES AND COLLECTIVE REPRESENTATION OF PLATFORM WORKERS
}

\begin{abstract}
The purpose of this short discussion paper is to outline the problems faced by collective labour law in face of new forms of work organization such as digital platforms. The digital economy has brought automation of work, digitalisation of processes and coordination by platforms. In comparison to other companies there are significant differences in the way platforms are organized and managed using algorithms. Employment platform workers have gone a long way from initial form of organising in self-help communities, guilds to co-operatives and full participation in trade union structures. Nowadays it has to be considered how to use technologies and data collected by platform companies to the benefit of workers.
\end{abstract}

Keywords: employment platforms, trade unions, collective representation, algorithmic management.

\section{CHODŹCIE Z NAMI! \\ NOWE TECHNOLOGIE I REPREZENTACJA ZBIOROWA PRACOWNIKÓW CYFROWYCH PLATFORM ZATRUDNIENIA}

Streszczenie. Celem niniejszego krótkiego opracowania jest zarysowanie problemów, z jakimi boryka się zbiorowe prawo pracy w obliczu nowych form organizacji pracy, takich jak platformy cyfrowe. Gospodarka cyfrowa przyniosła automatyzację pracy, cyfryzację procesów i koordynację przez platformy. W porównaniu z innymi przedsiębiorstwami istnieją znaczące różnice w sposobie organizacji i zarządzania platformami za pomocą algorytmów. Pracownicy platform zatrudnienia przeszli długą drogę od początkowej formy organizowania się we wspólnotach samopomocowych, cechach do spółdzielni i pełnego uczestnictwa w strukturach związków zawodowych. Obecnie należy się zastanowić, jak wykorzystać technologie i dane gromadzone przez firmy platformowe z korzyścią dla pracowników.

Słowa kluczowe: cyfrowe platformy zatrudnienia, związki zawodowe, reprezentacja zbiorowa, zarządzanie algorytmiczne.

${ }^{*}$ University of Business and Administration of Eugeniusz Kwiatkowski in Gdynia; joanna. unterschuetz@kadra.wsaib.pl 


\section{INTRODUCTORY REMARKS. CHARACTERISTICS OF EMPLOYMENT PLATFORMS}

In the recent years the phenomenon of labour platforms has attracted a growing body of research. The analysis and comparison of literature demonstrates that there are still gaps, especially insofar as reliable data on the scale of platform work in Europe. New forms of work appear and along with them new ways of workers' organisation, methods and areas of collective bargaining. The collective aspect of platform work is the main focus of this brief synthesis.

Labour platforms are defined as digital networks that coordinate labour service transactions in an algorithmic way (Pesole et al. 2018). However, it is not possible to approach platform work as a single and separate branch of economy. The COLLEEM survey analysed the tasks performed by platform workers and showed their enormous diversity: from online professional services, clerical work, software development and technology work, interactive services, through online micro-tasks, transportation and delivery services and on-location services such as housekeeping, beauty services, on-location photography services and similar (Pesole et al. 2018; Wood et al. 2019).

Not only do the platforms specialise in different areas of activities but they also adapt their architecture and management models to the needs of their clients. Platforms differ among themselves in terms of their role in connecting workers and clients, assigning tasks, the extent to which they exercise control over the work performed and the way they establish the terms of performing services including payment (Adams-Prassl, Risak 2017; Berg et al. 2011). This diversity together with different management patterns applied by the platforms pose significant challenges for organising platform workers.

The development of labour platforms has fuelled the discussion about the dusk of labour law and the diminishing role of collective representation. Less than 5 years ago it was difficult to imagine that platform workers will have access to trade unions or traditional forms of collective bargaining or co-determination (Degryse 2016). Certainly, not all platform workers are equally interested in trade union participation. For example, those who use worker-initiated moderately skilled work platforms could rather perceive themselves as real independent contractors, while online contest workers might see each other as competitors rather than possible trade union colleagues. In these groups, trade union participation does not seem likely to increase even if obstacles stemming from the form of employment were overcome.

For some other groups of workers, traditional approach to collective bargaining focusing mainly on fixing minimum rates of pay may not be sufficient. These differences are not unique for platform workers but rather reflect tendencies in fragmented labour markers (Vandaele 2018). 
Organising strategy can differ depending on a type of platform. Sometimes the platform acts rather as an intermediary, providing means that allow the conclusion of a contract between the person performing work on the platform or application and the client. Some platforms leave it up to the client and service provider to determine the amount of remuneration and transfer of payment, and may set minimum rates. Platforms may also allow direct contact between the client and the person carrying out the task (Eurofound 2015). This means that some platforms are organised in a way that resembles employment agencies or temporary work agencies (Adams-Prassl, Risak 2017). In Scandinavian countries, some platform companies register as temporary employment agencies (Chabber in Denmark and Instajobs and Gigstr in Sweden) and the workers are covered by collective agreements for temporary agency work, which helps to improve their pay and working conditions (Jesnes 2020).

\section{EARLY FORMS OF SELF-ORGANISING}

In case of online crowdworking platforms (such as Amazon Mechanical Turk) in the beginning workers organised themselves to achieve common goals by creating "first aid" communities and increasing the scope of available information, comparing entities for which they provide services, and as a result, gaining a better negotiating position (Aloisi 2016; Unterschütz 2019). One of the most successful example is the Turkopticon started by Lilly Irani and Six Silberman in 2009 (Irani, Silberman 2013; Degryse 2016). The platform allows people working for Amazon Mechanical Turk to organise and to protect their interests. It is interesting to note that the site uses a tool similar to these applied in algorithmic management practice of the platforms - the ratings. In Turkopticon the worker can install an overlay on the web browser, in order to follow the ratings given to service providers by previous contractors, and thus avoid performing work for those who have committed abuses (Irani, Silberman 2013; Degryse 2016). There are multiple other examples of online self-organisation of platform workers, including those carrying out microtasks. They range from online forum software chat channels, instant messaging software to private social media groups (Lehdonvirta et al. 2016). This also indicates the path that should be (and in many cases, is) adopted by trade unions in order to organise these workers.

\section{STATUS OF PLATFORM WORKERS AS AN OBSTACLE TO ORGANISE}

The main obstacle to organise in trade unions may be the legal status of platform workers. In crowdworking platforms, the tasks can be performed in a very short time (sometimes even a couple of minutes). The amount of time when 
the worker engages with the platform (excluding the time devoted to searching for appropriate tasks) may be too short to fall within the scope of European autonomous definition of a worker developed by the CJUE, as such work can be classified as marginal and ancillary (Unterschütz 2019). In some jurisdictions a contract in order to be classified as employment should engage worker for a given number of hours per week or per month. Consequently, the legal status of a worker may constitute a legal obstacle in organising in some jurisdictions. However in some countries self-employed persons can join trade unions and the recent amendments to the Polish trade union law broadened its scope and allow workers employed on the basis of civil law contracts and self-employed to join and form trade unions.

Within some of the platforms, the contract is concluded between the person carrying out the task and the platform. The work is ordered via the electronic platform and delivered to entities managing it. Such platform also determines the conditions of work performance and the amount of remuneration (Saxton et al. 2013; Adams-Prassl, Risak 2017). Then, despite formal objections, cooperation agreements with the platform or application may contain strict and stringent guidelines on how to perform work, as well as a work quality control system usually implemented through a system of assessments issued by clients (Felstiner 2010). Long-term relationships based on subordination connecting the platform and people performing work indicate that the activity of persons providing services on platforms and applications may be qualified as subordinated work (Adams-Prassl, Risak 2017; Felstiner 2010).

In order to organise platform workers, trade unions also take the strategy to challenge workers' misclassification as self-employed. One of the well-known examples is the case supported by GMB, followed by similar cases in Italy and France (Kenner 2019; Johnston 2019; Unterschütz 2020). There are also smaller unions formed to represent precarious workers like the Independent Workers Union of Great Britain (IWGB) in the UK or the New York Taxi Workers Alliance - NYTWA (Johnston 2019).

An interesting solution was adapted in the collective agreement covering Danish Hilfr and 3F platforms: it allows platform workers that have worked more than 100 hours to decide themselves if they want to be self-employed or employees covered by the terms of the agreement (Jesnes 2020).

Even if the legal status of persons performing work on platforms or applications is difficult to determine, it should not be an obstacle to the freedom of association. First of all, it should be borne in mind that in international law, and in particular under the ILO Convention, the freedom of coalition does not only include employees within the meaning of national regulations, but also other groups of people engaged in paid work, including self-employed workers. In art. 2 of ILO Convention No. 87 was granted to employees without any distinction, the right to form and join organisation at their own discretion. As the Union 
Freedom Committee points out, "determining who has the right to coalition is not based on the criterion of an employment relationship that often does not exist. This is the case, for example, for agricultural workers, self-employed workers or freelancers who can still exercise their right to associate in trade unions". This can certainly also be applied to people who work within digital platforms.

\section{TRADE UNION INITIATIVES}

Even though trade unions tended to primarily focus on standard employment, there are many that adapt their strategies and change their structures to reach out to non-standard workers, including platform workers (OECD 2018). Still, most initiatives cover workers doing on-location platform-determined tasks (such as food couriers and drivers) because this form of work facilitates organization of workers (Eurofound 2019). It is difficult to find initiatives aiming at on-location worker-initiated work or online contest work, therefore many platform workers still do not have collective representation (Eurofound 2019).

Numerous examples confirm that the traditional trade unions embrace atypical (including platform) workers or even adapt their structure to be able to serve this group of people (Aloisi 2019; de Groen at al. 2018; Akgüç et al. 2018). The German trade union IG Metall, inspired by Turkopticon, created the FairCrowdWork platform which has collaborators among many trade unions - not exclusively from Europe. This site goes further than Turkopticon, presenting not only ratings of the platforms, but also information on working conditions and remuneration offered by forums that use their services, as well as the exchange of views and experiences and use of legal assistance offered by the trade union. IG Metall is also open to self-employed members since January 1, 2016, with a focus on crowd- and platform-based workers (Eichhorst, Schoeder 2018). It is also one of the co-initiators of the Frankfurt Declaration on PlatformBased Work. The paper calls on the diverse stakeholders to "platform-based work" to work together to ensure basic labour rights and social protection as well as the right to organise.

Another example is Unione Italiana Lavoratori Turismo Commezio Servizi (UILTuCS) - an Italian trade union which offers individual support to platform and app workers as well as seeks the means to organise and represent them in negotiations with industry representatives. Couriers and Logistics Branch of the Independent Workers of Great Britain is defending the rights of workers in the British courier and logistics industry, including self-employed workers for major courier companies and food delivery companies such as Deliveroo and UberEats (Wordpress 2017; Wordpress 2019). Freelancers Union 118 signed a partnership with Lyft, offering the possibility for Lyft drivers to obtain such benefits as entering the pressure group's health plan (Aloisi 2016). All these unions use online 
channels to reach out to platform workers and offer services designed especially for this group of members.

In order to fit within the Polish legal framework, trade unions need to operate at the employer's company. They can also create multi-establishment organisations. This means that workers of a particular platform (e.g. Uber Eats) need to establish trade union organisation and register it. Such an organisation needs to have its own statute, authorities seat etc. (Piątkowski 2008), which puts a large administrative burden on precarious workers. This type of organisation of trade unions better fits traditional Fordist model of production than contemporary companies. It seems that better results in organising platform workers are achieved in such countries as Sweden, Denmark, Germany or France, where trade union organisations are located outside the companies.

\section{TECHNOLOGY - A FRIEND OR A FOE?}

The same technology that plays predominant role in algorithmic management in platforms may be used to support freedom of association. In companies applying algorithmic management techniques an unprecedented degree of oversight and control is possible (Schildt 2017). As many activities leave a digital trace, these patterns can now be inexpensively collected and mined for insights into how people work and communicate, potentially opening doors to more efficiency and innovation within companies. In "traditional" work environments, decision implementation is the responsibility of human managers, but in many platform contexts, data-driven management decisions are made and enacted automatically on the basis of algorithm calculations with little or no human intervention (Möhlmann, Zalmanson 2017). In contrast to Taylorism, algorithmic management techniques enabled by platform-based rating and ranking systems facilitate high levels of autonomy, task variety and complexity, as well as potential spatial and temporal flexibility (Wood et al. 2019). Presumably automated decisions, contrary to the human ones are free of bias and as such prevent discrimination against workers based on factors such as ethnicity or disability status. However, much depends on the design of the algorithm. If it is programmed in an unfavourable way, it can increase discrimination or be so rigid in proposing tasks that the workers' flexibility and autonomy are severely limited (Mandl 2019).

Algorithms rely upon an explicit set of rules, so it could be relatively easy to increase the transparency of algorithmic management processes. However, companies are reluctant to disclose them, therefore, creating very low transparency for workers and customers to gain an information advantage (Möhlmann, Zalmanson 2017). Trade unions could also play a role in co-designing these algorithms just as they participate in creating other management procedures in companies. Such issues as the algorithm formula or necessary corrections 
constitute an important subject for negotiations between the platform and workers' representatives. In this way, a lot of data collected form workers could be used to their advantage in the process of negotiating pay rates, organising working time, and in grievance mechanisms or even create new forms of workers representation (Choudary 2018). Trade union applications would be an easy solution for platform workers to see, compare and adhere to the offer of trade unions just by downloading and activating an application. The same tool could be used to calculate and collect trade union fees. Access to data collected by the platform opens the way for the trade unions and their representatives to use automated negotiation processes as well.

The technical solution that enables automatic negotiation is the API (Application Programming Interface). It could also be used for the benefit of workers in other ways. The fact that humans do not interact directly with the API and as a consequence do not have direct access to data on the server make this technology suitable for interactions between platforms and trade unions or their workers. In order to make this technology viable for the purpose, namely trade union interaction with the platform as well as conducting collective bargaining, the platform and workers' representatives should first of all agree what categories of data are to be shared and how they are going to be used by trade unions or workers directly.

Trade unions should make greater use of digital technology in order to meet the needs of workers whose working conditions are strongly determined by algorithmic management.

\section{CLOSING REMARKS}

Platform workers' collective activism has come a long way from singleplatform oriented self-help initiatives, through various forms of co-operation with trade unions towards becoming members of traditional trade union organizations. This allows platform workers to benefit from experience, experts, organisational and financial resources of these organisations - just like other workers. Platform workers can also create their own forms of organisations perhaps better fitted to their needs or the way platforms operate, such as platform co-operatives.

Despite all obvious technical differences the route followed by platform workers in order to organise themselves bears some resemblance to early trade union movements. This is especially visible as we observe riders' protests organised in various countries.

Recent study by the ETUS has shown that regardless of technology applied to manage platforms there is still a need to act together and undertake the effort of collective bargaining. New technological developments create new areas of negotiations, such as transparency of data processing, workers' ratings, privacy, 
etc. Still some traditional fields of negotiations, such as pay remain valid not only for platform workers but for the vast majority of precarious workers, and this can be achieved easier through collective effort.

\section{BIBLIOGRAPHY}

Adams-Prassl, Jeremias. Martin Risak. 2017. "Uber, TaskRabbit \& Co: Platforms as Employers? Rethinking the Labour Law of Crowdwork". In The New Foundations of Labour Law. Edited by Kerstin Ahlberg, Niklas Bruun. Frankfurt am Main: Peter Lang.

Akgüç, Mehtap. Miroslav Beblavý. Elina Cirule. Zachary Kilhoffer. 2018. Industrial Relations and Social Dialogue in the Age of Collaborative Economy (IRSDACE) Comparative Report. Brussels: Jobs \& Skills Unit - CEPS. https://www.ceps.eu/wp-content/uploads/2018/12/ IRSDACE Comparative.pdf

Aloisi, Antonio. 2016. “Commoditized Workers. Case Study Research on Labour Law Issues Arising from a Set of 'On-Demand/Gig Economy' Platforms". Comparative Labor Law \& Policy Journal 37(3): 653-690.

Aloisi, Antonio. 2019. Negotiating the Digital Transformation of Work: Non-Standard Workers' Voice, Collective Rights and Mobilisation Practices in the Platform Economy. Italy: European University Institute.

Berg, Janine. Marianne Furrer. Ellie Harmon. Uma Rani. M. Six Silberman. 2011. Digital Labour Platforms and the Future of Work. Towards Decent Work in the Online world. Geneva: International Labour Office.

Choudary, Sangeet Paul. 2018. The Architecture of Digital Labour Platforms: Policy Recommendations on Platform Design for Worker Well-being. Geneva: International Labour Office.

de Groen, Willem Pieter. Zachary Kilhoffer. Karolien Lenaerts. Irene Mandl. 2018. Employment and Working Conditions of Selected Types of Platform Work. https://www.eurofound.europa. eu/publications/report/2018/employment-and-working-conditions-of-selected-types-ofplatform-work

Degryse, Christophe. 2016. Digitalisation of the Economy and Its Impact on Labour Markets. Working Paper 2016.2. Brussels: ETUI.

Eichhorst, Werner. Wolfgang Schroeder. 2018. The German Employment Model, the Trade Unions and "Working 4.0". Bratislava: Friedrich-Ebert-Stiftung I Regional Project on Labour Relations and Social Dialogue.

Eurofound. 2015. New Forms of Employment. 3 March 2021. https://www.eurofound.europa.eu/ topic/new-forms-of-employment.

Eurofound. 2019. On-location Client-determined Moderately Skilled Platform Work: Employment and Working Conditions. Publications Office of the European Union: Dublin. https://www. eurofound.europa.eu/pl/data/platform-economy/records/on-location-client-determinedmoderately-skilled-platform-work-employment-and-working-conditions

Felstiner, Alek. 2010. "Working the Crowd: Employment and Labor Law in the Crowdsourcing Industry". Berkeley Journal of Employment and Labor Law 32(1): 143-203. https://ssrn.com/ abstract $=1593853$ [Accessed: 10 May 2017].

Irani, Lilly C. M Six Silberman. 2013. "Turkopticon: Interrupting Worker Invisibility in Amazon Mechanical Turk". In Proceedings of the SIGCHI Conference on Human Factors in Computing Systems (CHI '13). 611-620. New York: Association for Computing Machinery. http:// crowdsourcing-class.org/readings/downloads/ethics/turkopticon.pdf [Accessed: 14 February 2020]. 
Jesnes, Kristin. Anna Ilsøe. 2020. "Collective agreements for platform workers? Examples from the Nordic countries". In Platform Work in the Nordic models. Issues, cases and Responses. Edited by Kristin Jesnes, Sigurd M. Nordli Oppegaard. 53-67. Copenhagen: Nordisk Ministerråd. https://norden.diva-portal.org/smash/record.jsf?pid=diva2\%3A1431693\&dswid=2916

Johnston, Hannah. Christopher Land-Kazlauskas. 2019. Organizing on-demand: Representation, Voice and Collective Bargaining in the Gig Economy. Geneva: International Labour Office.

Kenner, Jeff. 2019. "Uber Drivers are 'Workers': The Expanding Scope of the 'Worker' Concept in the UK's Gig Economy". In Precarious Work. The Challenge for Labour Law in Europe. Edited by Jeff Kenner, Izabela Florczak, Mark Otto. 197-220. Cheltenham, Northampton: Edward Elgar.

Lehdonvirta, Vili. 2016. "Algorithms that Divide and Unite: Delocalisation, Identity and Collective Action in 'Microwork". In Space, Place and Global Digital Work. Edited by Jörg Flecker. 53-80. London: Palgrave Macmillan.

Mandl, Irene. 2019. Platform Work: Maximising the Potential while Safeguarding Standards? Dublin: Publications Office of the European Union. https:/www.eurofound.europa.eu/publications/ policy-brief/2019/platform-work-maximising-the-potential-while-safeguarding-standards

Möhlmann, Mareike. Lior Zalmanson. 2017. "Hands on the Wheel: Navigating Algorithmic Management and Uber Drivers' Autonomy”. Paper presented at Thirty Eight International Conference on Information Systems (ICIS 2017). December 10-13. Seoul, South Korea.

OECD. 2018. Negotiating Our Way up. Collective Bargaining in a Changing World of Work. Paris: OECD Publishing. https://doi.org/10.1787/1fd2da34-en

Pesole, Annarosa. Maria Cesira Urzí Brancati. Enrique Fernández-Macías. Federico Biagi. Ignacio González Vázquez. 2018. Platform Workers in Europe. Evidence from the COLLEEM Survey. Luxembourg: Publications Office of the European Union.

Piątkowski, Jan. 2008. Uprawnienia zakładowej organizacji zwiąkowej. Toruń: TNOIK.

Saxton, Gregory D. Onook Oh. Rajiv Kishore. 2013. "Rules of Crowdsourcing: Models, Issues, and Systems of Control". Information Systems Management (30)1: 2-20. http://dx.doi.org/10.108 0/10580530.2013.739883 [Accessed: 12 March 2017].

Schildt, Henri. 2017. "Big Data and Organizational Design - The Brave New World of Algorithmic Management and Computer Augmented Transparency". Innovation (19)1: 23-30.

Unterschütz, Joanna. 2019. "Digital Work - Real Bargaining: How Can the Sustainability of Social Dialogue Be Ensured in the Digital Era?" In Precarious Work. The Challenge for Labour Law in Europe. Edited by Jeff Kenner, Izabela Florczak, Marta Otto. 222-242. Cheltenham: Edward Elgar Publishing.

Unterschütz, Joanna. 2019. "The Concept of the 'Employment Relation"” In The Charter of Fundamental Rights of the European Union and the Employment Relation. Edited by Filip Dorssemont, Klaus Lörcher, Stefan Clauwaert, Mélanie Schmitt. 81-100. Oxford: Hart Publishing.

Unterschütz, Joanna. 2020. Digital Labour Platforms: Dusk or Dawn of Labour Law? [Manuscript].

Vandaele, Kurt. 2018. Will Trade Unions Survive in the Platform Economy? Emerging Patterns for Platform Workers' Collective Voice and Representation in Europe. Working Paper 2018.05. Brussels: ETUI.

Wood, Alex J., Mark Graham. Vili Lehdonvirta. Isis Hjorth. 2019. "Good Gig, Bad Gig: Autonomy and Algorithmic Control in the Global Gig Economy". Work, Employment and Society 33(1): $56-75$.

Wordpress. 2016. "UberEats \& Deliveroo Update”. 7 September 2016. https://iwgbclb.wordpress. com/2016/09/07/ubereats-deliveroo-update/

Wordpress. 2017. "Brighton Deliveroo Strike leads to unionisation". 7 February 2017. https:// iwgbclb.wordpress.com/2017/02/07/brighton-deliveroo-strike-leads-to-unionisation/ 